\title{
Banking Strategies and Customer Loyalty Case of Tunisian Banks
}

\author{
Chiraz Rouissi \\ University of Jeddah, Jeddah, KSA \\ Email: charrouissi@yahoo.fr
}

How to cite this paper: Rouissi, C. (2021). Banking Strategies and Customer Loyalty Case of Tunisian Banks. Open Journal of Business and Management, 9, 877-893. https://doi.org/10.4236/ojbm.2021.92047

Received: February 13, 2021

Accepted: March 28, 2021

Published: March 31, 2021

Copyright () 2021 by author(s) and Scientific Research Publishing Inc. This work is licensed under the Creative Commons Attribution International License (CC BY 4.0).

http://creativecommons.org/licenses/by/4.0/

\begin{abstract}
In recent years, the marketing of services, long in search of academic legitimacy, has found a clear recognition of its specificities. Banking marketing, a component of the services sector, is getting a promising boost from this development. The present research is proposed to study the development of the activity of banking strategies and customer loyalty introduced in banks to enable them to optimize the quality of communication and satisfaction while generating more profits and trust.
\end{abstract}

\section{Keywords}

Banking Marketing, Satisfaction, Trust, Loyalty, Communication

\section{Introduction}

For more than twenty years, in France, like the United States, financial organizations have shown new enthusiasm for management concepts and, in particular, an increased interest in the marketing aspect of their management. The marketing of services, long in search of academic legitimacy, has found a clear recognition of its specificities. Banking marketing, a component of the services sector, is getting a promising boost from this development. Although, marketing is related to markets, marketing management requests for combination of the various elements of market. It has the mission of structuring these factors into a successful trading system so that it can serve both customer and business company effectively.

The specific marketing of the bank had to leave its reserve to become more and more akin to "common law" marketing based on full exploitation of all its tools and a differentiated approach.

Each of its stages corresponds to the progress of marketing services in three phases: "rampant" marketing, flight in. 
The new competitive environment has visibly stimulated the renewal of the concept of the banking profession, its practices, and its image.

Since the 1980s, the banking sector has undergone profound changes, probably more remarkable than those in any other sector: deregulation, increased competition, but also changes in activities and operating costs in the face of a more demanding clientele, better trained and informed.

Initially, and in a purely theoretical context, all the facts and ways of approaching marketing in a bank were explained and the need for existence was demonstrated.

Some studies have been done on the impact of some marketing components' relationship on loyalty (Bergeron et al., 2003; Boyer \& Nefzi, 2008; Moulins \& Roux, 2008; Alrubaiee \& Al-Nazer, 2010). For example, Bergeron et al. (2003) in their study on determinants of commercial customer loyalty in the Canadian banking industry, identified trust and satisfaction as having a significant impact on loyalty.

Boyer and Nefzi (2008) investigated the relationship between quality perception and loyalty. Also, Intissar et al, (2020) have established a model that links marketing variables relationship (trust, commitment) to dimensions of loyalty (loyalty by conviction, loyalty through inertia, and loyalty through conformism).

The challenge of the quality of this experience is the survival of the bank (Rouissi \& Frioui, 2014). Let us never forget that competitors also deploy their strategies, they too struggle to retain their customers and attract new ones and change the behavior of our customers in their favor.

This has led us to pose the following problem: does relational marketing play a crucial role in the development of customer loyalty at the banking?

The first part will be presented banking marketing through its evolution, consumer behavior and different marketing tools, and banks' strategies. In the second part, we will discuss the results of the quantitative study conducted. In a conclusion, some avenues of research will be developed.

\section{Literature Review}

According to Theron \& Terblanche (2010), "The relationship marketing is essentially relationship building (2010) level of all points of interaction with the client, with the intention of to create profits for him and the company".

Others, like Benamour \& Prim (2000), "I conceive as a customer-oriented strategy that creates the added value for both parties and guarantees long-term profit”. Benamour and Prim (2000) also identify as an attitude based on emotional orientation, (economic) and temporal functions of the customer, as well as contextual factors.

Of the various aspects of marketing, which have not yet been introduced into the bank, only the communication policy seems to be of possible use but of still poorly perceived usefulness. Any product policy based on diversification or innovation is impossible to conceive; the distribution policy is submitted to the 
National Credit Council (NCC) and the price policy is liable to prosecution before the Bank Control Board (BCB) (The Bulletin of the European Communities reports, 1983).

The bank of that time has a limited clientele and where the possession of a bank accounts with a strong social connotation. If the bank then tries to use communication, it is essential to reinforce this distant image.

But an important development is beginning. The place of the banking currency is growing, the access to bank services is underway, under the influence of economic growth, rising living standards, will have a significant impact on banking activity.

So, it seems quite legitimate that it was in the mid-1960s that the bank was interested in expanding marketing.

From the mid-1960s, banks gradually developed their marketing activities. Their approach obeys both a fashion phenomenon and a real need.

In all sectors, the increased competition encourages manufacturers and distributors to take an interest in the expectations of their potential customers.

Economic and social developments lead to bank services for all and bring the "public banking service" into the universe of fundamental consumer and citizen rights. Beyond the expectations of the clientele, the requirements of the citizen appear.

The urgency of a major marketing effort appears very quickly. The liberalization of banking conditions and the massive opening of new branches make the bank appear closer to the public.

This evolution reflects a change in the banking behavior of the public. On the one hand, the new unbanked are less and less fortunate, and, on the other hand, the amounts left on-demand accounts tend to decrease due to the existence of new forms of investment (e.g.: housing savings, with attractive profitability and liquidity).

The relationship with the bank is perceived by these new customers as the fruit of an obligation, resulting from the monthly payment of salaries, and not as a deliberate choice.

As early as 1984, the foundations for a new organization of the bank were laid. But consumers are beginning to see with some irritation the willingness of banks to pay for the free services through which they once attracted their customers.

1984 was a pivotal year in the organization of banking supply, which was hitherto little concentrated. But on 31 July 1984, the group of so-called CB bank cards was created, and the banking offer was standardized, offering an exceptional service that is still unmatched to any $\mathrm{CB}$ cardholder: possible use in all ATMs and at all merchants in France (Fasnacht, 2018).

Companies, the main borrowers, use direct, non-bank financing, through deregulation measures: shares and notes (from 1986).

At the same time (from 1978 to 1989), the customers of the banks for the credit activity shifted: the share of enterprises in the form of companies decreased to the benefit of individuals and individual entrepreneurs. The latter two catego- 
ries, which have been neglected for a long time by the credit framework, can now be better satisfied. On the other hand, larger companies opt more frequently for direct financing. And the behavior of the banking consumer change. In any consumer decision-making process, one can distinguish between the pre-purchase, the actual purchase, and the post-purchase phases (Fasnacht, 2018).

Many general models of consumer behavior have been proposed. There are five distinct phases in the purchasing decision to be imposed in Figure 1.

But not all types of purchases necessarily follow such a complex logic: some purchases are impulsive or routine, others are thoughtful.

For example, the choice of a bank is made in a very different way by the tourist looking for an exchange window for his currency during a stay abroad, the client who wants to make a cash withdrawal in an ATM, and the future buyer of housing in search of financing.

The loyalty to a supplier can be explained, not only by the satisfaction obtained in previous experiments but also by the small number of offers available or by the importance of the costs of changing suppliers (Azzouzi \& Naoui, 2020).

There are several reasons for limiting the number of offers taken into consideration by the consumer. First, each provider offers only a range of service options, or even one. To obtain a wider choice, the buyer will have to request several suppliers. The limitation also comes from the small number of competitors in the same market: a defined geographical area cannot sustainably accommodate many suppliers of the same type of service.

Many factors influencing the banking consumer (Fawcett et al., 1992; Moital 2007), there are different forms of purchase: Firstly, the fully programmed purchase, which leads to defining in advance two major components of the act: the type of product and the place of purchase, for example for the subscription of a type of investment defined in a chosen bank.

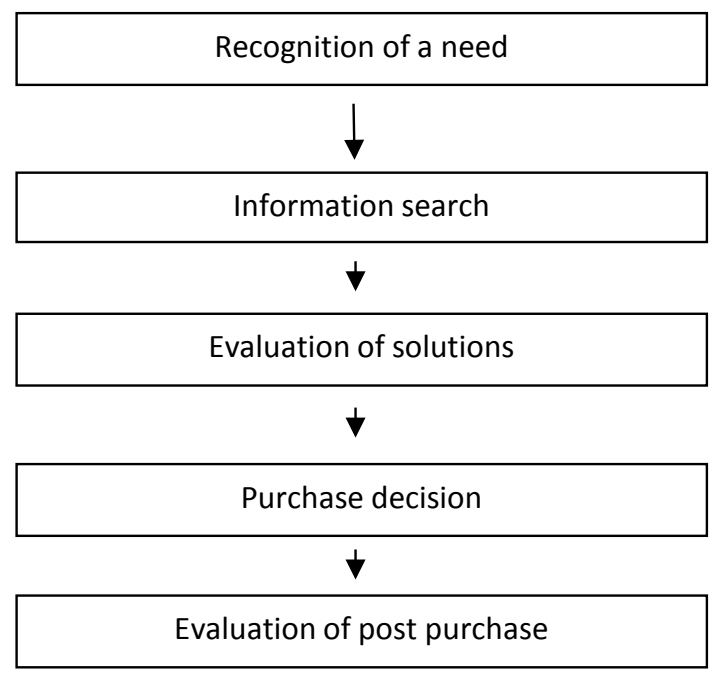

Figure 1. Phases of purchasing decision. Source: Adapted from (Fawcett et al., 1992; Moital, 2007). 
Secondly, the partially programmed purchase, which consists of defining the bank or service desired and then choosing the other component: for example, the tourist who wants to convert his currency can choose a bank at random from his itinerary, or the client who wants to make an investment contacts his bank and chooses with his contact the type of investment.

The concept of "customer loyalty" is central to the marketing managers, and for good reason. Indeed, ensuring the loyalty of customers has become impressive (Reichheld \& Schefter, 2000). They studied online loyalty (e-loyalty), analyzing the strategies and practices of many large Internet companies and polling thousands of their customers, with surprising results. Indeed, in the haste to create Internet businesses, many executives mistakenly focus all their attention on attracting customers rather than on their loyalty. A loyal business buys over a long period, is less influenced by prices (Keaveney, 1995; O'Brien \& Jones, 1995) and talks positively about the company to their loved ones (Reichheld \& Teal, 1996; Palmatier \& Steinhoff, 2019). Indeed, trust is a major component of the relationship-based approach loyalty. Several authors have confidence as an important component of the quality of the relationship (Melewar et al., 2017).

Commitment has now become an unavoidable variable in the theory of relationship marketing.

Morgan \& Hunt (1994) consider it the will of a consumer to pursue a relationship with a partner. The manifestation of the commitment between the customer and his bank is perceptible through the customer's actual efforts to maintain the relationship with their bank (behavioral commitment). The consequences of such a commitment are brand or attendance at the point of sale by the customer, to continue the relationship and the resistance to change. However, it should be noted that the customer's commitment to his bank can be calculated that the customer remains attached to his bank because the cooperation makes a profit, it can also be described as instrumental; either the commitment is to develop when customers find themselves obliged to maintain the relationship due to costs high and risks related to a change of trading partner or lack of opportunities satisfactory. In fact, the dimensions of banking customers are imposed in Figure 2.

- The behavior of the customer-consumer (Hrishikesh et al., 2019) is analyzed according to his needs. To meet its expectations, the bank structures its offer in such a way as to constitute differentiated families of products and services that meet each of the needs of the customer-consumer segments. The offer is no longer presented as a set of intangible products but as an understandable and materialized response to a need.

The behavior of the client-prospector is studied according to its process of choosing a point of sale. It thus appears two forms of customer-prospector:

- The customer flows, who chooses the point of sale because of its proximity or ease of access.

- The customer traffic, who chooses the point of sale for reasons that proximity: word of mouth, brand image, family habits, search for specific skills. 


\begin{tabular}{|c|c|c|}
\hline Dimension & Analyzed content & Result \\
\hline Consumer & Type of customer need. & Segmentation and structuring of the offer in concrete responses to needs \\
\hline Prospector & Point of Sale Selection and Attachment & Retention of both types of prospector. \\
\hline Buyer & Type of Procurement Decision Process & Layout of premises, definition of staff tasks, information, response times \\
\hline
\end{tabular}

Figure 2. The dimensions of banking customers. Source: Yvonne and Jackman (2002).

- The behavior of the client-buyer is analyzed to detect the perception of products and peripheral offers from the point of sale. This includes detecting, among the different types of products, those that are the subject of spontaneous purchases and those that trigger a more complete decision-making process.

The quality of communication is reflected in a communication based on an information dialogue related to customer needs, interests, and preferences (Morgan \& Hunt, 1994). Within financial institutions, Bruhn (2000) adds that the quality of internal communications has a significant impact on the quality of communications.

Through the customers the information will be provided to them and will be correct and accurate. Indeed, the communication variable traditionally has several dimensions: external communication, aimed at the various corporate audiences, and internal communication aimed at staff.

Through this article, banking communication is a set of codes issued by the bank to its customers to ensure favorable feedback to shine their reputation among its competitors. External communication can focus on several themes and objectives.

- information; it covers product and institutional, it has image or awareness objectives. Awareness campaigns are much less prevalent today than they were 20 years ago because retailers feel that they have reached a level of awareness deemed satisfactory.

Product information campaigns are mainly used for new product launches. But each campaign is beneficial to compete for brands. The image of the bank is particularly visible between the behavior, positive if we judge by the rate of binarization, and the attitude, reflected by negative opinions.

There are two modes of communication: under intra- and extra-sectoral competitive pressure, banks renewed their communication policy. This questioning is evident in the choice of media used. The advertising takes back all its interest at the expense of the media (direct marketing, promotion). The content of the advertising itself has been revised: it is now oriented towards consumer benefit without becoming too informative or factual or sacrificing the emotional dimension.

The Satisfaction variable is therefore fundamentally a judgment, an assessment that integrates, on the one hand, the perceived quality (consumer experience) and on the other hand the attentats prerequisites. Experience greater than or equal to expectations creates a sense of satisfaction experience below ex- 
pectations leads to dissatisfaction.

\section{The Conceptual Model}

The customer loyalty is a concept that has been widely used as a key success factor. In fact, according to a certain author, it constitutes one of the measures of satisfaction and therefore generally includes attributes relating to the communication provided by the customer loyalty such as the commitment and the trust.

To better understand the context of the study, the conceptual framework is mapped out as in Figure 3.

As part of this research, the aim is to verify the impact of trust on loyalty in a context that is the Tunisian banking sector. So, first, the assumptions associated with trust in the bank will be presented and then compared to the staff in contact. Trust-loyalty.

Consequently hypothesis

Once the primary research question is indicated, it is fairly easy to formulate more operational assumptions. A hypothesis is an anticipated response to the research problem, expressing a relationship between two or more concepts. This is the decline of the problem in operational terms, and a prediction must be made about a result (Paille \& Mucchielli, 2003).

Hl: The more confident consumers feel, the more loyal they are to the bank.

H2: The more bank customers are engaged, the more loyal they are to the bank.

H3: The more satisfied customers are, the more loyal they are to the bank.

H4: Quality communication should increase the loyalty of bank customers as to the bank they are dealing with.

\section{The Accuracy and Validity of the Measurement Scales}

Before starting the various statistical analyses, it is important to check the accuracy and validity of the measurement scales used. According to Paille \& Mucchielli (2003), loyalty is defined as the degree to which the research instruments used consistently measure the construct studied, whereas the validity corresponds to the degree to which the research instruments used measure perfectly the constructed studied. Factorial analysis as the main component will make it possible to verify, in part, the validity of our constructs and the alpha of Cronbach, the reliability of our constructs (Dhakal, 2018).

Factor analysis is an approach that reduces the amount of Information on a given topic to a small number of elements (Stafford \& Bodson, 2006). The objectives of such an analysis are: 1) to study the interrelationships between a fairly large number of variables; 2) to group these variables into limited groups called factors or components; and 3) to establish a hierarchy between these groups of variables based essentially on the explanatory value of each of them (Stafford \& Bodson, 2006). 


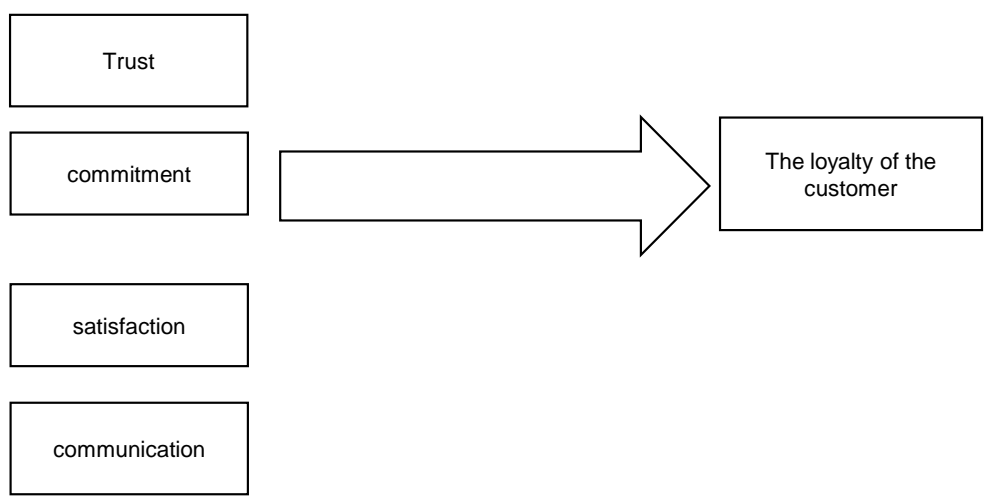

Figure 3. The components of the relationship approach. Source: Karim \& Habiba (2020).

It is also important to note that factor analysis of the grouped independent variables was performed, but several variables had high scores on two factors at a time or different factor statements were grouped under the same factor. So the discriminant validity is low. But because we wanted to assess the impact of each factor, independent analyses were carried out. However, we have analyzed the convergent validity of our measuring instruments. This analysis makes it possible to check whether different indicators that are supposed to measure the same phenomenon are correlated (Evrard, Pras, \& Roux, 1993: p. 284).

According to Park and Kim (2000), loyalty is defined as the degree to which the research instruments used consistently measure the construct studied, whereas the validity corresponds to the degree to which the research instruments used measure perfectly the constructed studied.

\subsection{The Sample Selection}

Our study population will be made up of customers of commercial banks operating in Tunisia. So, we will proceed to the determination of the parent population that consists of Tunisian bank branches ( 43 bank branches) which have the characteristics for the study.

Respondents are executives and agency leaders from banks and Tunisian bank branches (ABC, AL BARAKA, AMEN BANK, ATB, BCT BFPME, BFT, BH, BIAT, BNA, BT, BTE, BTK, BTL, BTS, CITI BANK, NORTH AFRICA INTERNATIONAL BANK, STB, STUSID, TIB, Tijari Bank TQB, UBCI, ZITOUNA UIB, WIFAK BANK).

\subsection{Method of Data Analysis}

The counting of questionnaire data obtained will be realized through the SPSS Version 18. This software allows describing the data and performing all desired analyzes. Flat sorting and multivariate methods (factor analysis).

\section{Result and Discussion}

The factor analysis may be applied to each built research. This is a technique to 
reduce the number of factors and move to a more realistic number.

For confidence analysis, the statements "In the event of a conflict, the bank would make significant efforts to resolve it", "The customer managers have the necessary skills to meet customer requirements", "The account managers are flexible to ensure the sustainability of the relationship" were eliminated as they had factor scores below .50. The analysis of the main components resulted in two the analysis of the main components yielded two components (Eigenvalues $=6.433$ and $5.8>1$ ) in Table 1 .

For engagement analysis, the first component includes 5 statements. The second component consists of 2 statements.

The analysis of the main components revealed two components (Eigenvalues $=4.007$ and $2.355>1$ ) in Table 2 .

For communication analysis, the single component includes 4 . The analysis of the main components revealed two components (Eigenvalues $=4.007)$ in Table 3.

Table 1. Factor confidence analysis.

\begin{tabular}{lll}
\hline The measuring scales & The component \\
\cline { 2 - 3 } & 1 & 2 \\
\hline 1-I have confidence in the quality of this bank's financial services & .880 & .260 \\
2-I am not taking any risks in doing business with this bank & .760 & .420 \\
3-This bank is an expert in its field of activity & .801 & .340 \\
4-This bank will think of the interests of its customers & .660 \\
5-This bank constantly seeks to improve its responses to the needs of its & .690 & .780 \\
customers & .60 & .820 \\
6-I find that the customer managers circulate precise information on each & .540 & .690 \\
operation & & .880 \\
7-The customer is always the king & .420 & .680 \\
$8-$ The customer managers are flexible to ensure the sustainability of the & 6.433 \\
relationship & 5.8 \\
Eigenvalue & .750 \\
Alpha of Cronbach & & .755
\end{tabular}

Source: Personal Calculation.

Table 2. Factor analysis of engagement.

\begin{tabular}{lll}
\hline & \multicolumn{2}{l}{ The component } \\
\cline { 2 - 3 } The measuring scales & 1 & 2 \\
\hline 1-I have a sense of belonging to this bank & .980 & .220 \\
2-I am particularly loyal to this bank & .880 & .325 \\
3-I am satisfied to be a customer of this bank & .68 & .450 \\
4-I will continue to use the services of this bank as long as there are & .790 & .590 \\
other more satisfactory banks & & .770 \\
5-This bank has enormous advantages that I currently enjoy & .677 & 2.355 \\
Eigen value & 4.007 & .725 \\
Alpha of Cronbach & .745 & \\
\hline
\end{tabular}

Source: Personal Calculation. 
Table 3. Factor analysis of communication.

\begin{tabular}{ll}
\hline The measuring scales & The component \\
\cline { 2 - 2 } & 1 \\
\hline 1-Any information likely to help the customer is transmitted to him & .890 \\
2-Exchange of information takes place on a regular basis & .799 \\
3-Each partner keeps the other informed of any event or change & .860 \\
that would affect the other party & \\
4-Partners are expected to exchange confidential information if it .760 \\
is useful to the other party \\
Eigen value \\
Alpha of Cronbach \\
\hline
\end{tabular}

Source: Personal Calculation.

For satisfaction analysis, the single component includes 4 statements. The analysis of the main components revealed two components (Eigenvalues = 3.737) in Table 4.

For loyalty analysis, the single component includes 8 statements. The analysis of the main components yielded a single component (Eigenvalues $=3.737$ ) in Table 5 .

The analysis of regression:

To study the relationships between the dependent variable and each of the independent variables, regression analysis is performed. This method is an analysis that presents the direction and shape of the relationship between a continuous dependent variable (simple regression) or several independent variables (multiple regression) (Dhakal, 2018). In the case of this article, the dependent variable is loyalty, while the independent variables are trust, satisfaction, commitment, and communication (Table 6).

Since Table 6, most variables (confidence, communication, engagement, and satisfaction) meet the assumption of normality of the variables. Only one loyalty variable does not meet the asymmetry criterion and remains above the threshold of .5 with a Skewness coefficient of -.690 . The distribution of this variable is slightly derived to the left (Table 7).

For the analysis of simple regression, we used two elements to assess the relationship between our dependent variable which is loyalty, and independent variables (Dhakal, 2018).

Table 7 shows that the model relating consumer confidence in the bank to loyalty is significant, with $p(\mathrm{~F} 0)=.000$. Besides, its impact is positive with a value of .720.

The model that links trust in the bank to loyalty displays an $\mathrm{R} 2=.480$ so this model is a linear model with acceptable explanatory power.

Indeed, the loyalty of Tunisian bank customers increases as the level of trust in the bank and its representative's increases. This result is consistent with that of Ndubisi (2006), who argue that trust is an important element in business-to-customer relationships and the development of loyalty and add that banks should strive to gain customer confidence. 
Table 4. Factor analysis of satisfaction.

\begin{tabular}{ll}
\hline The measuring scales & The component \\
\cline { 2 - 3 } & 1 \\
\hline 1-I am satisfied with the relationship I have established with this bank. & .950 \\
2-The services rendered by this bank are excellent & .980 \\
3-I have good experience with this bank & .887 \\
4-I am satisfied with the relationship I have established with the staff of this bank .920 \\
Eigenvalue & 3737 \\
Alpha of Cronbach & .788
\end{tabular}

Source: Personal Calculation.

Table 5. Loyalty factor analysis.

\begin{tabular}{ll}
\hline The measuring scales & The component \\
\cline { 2 - 2 } & 1 \\
\hline 1-This bank has competitive banking products. & .870 \\
2- I believe my bank has the best offers & .842 \\
3-I like the features of the offer and service of this bank & .770 \\
4-I believe that this bank is more efficient than the others & .699 \\
5-This bank meets my requirements & .821 \\
6-Each time I realize that this bank is better than the others & .901 \\
7-I would like to try another bank if it offers more advantages than this bank & .620 \\
8-I will always continue with this bank & .725 \\
Eigen value & 6248 \\
Alpha of Cronbach & .766
\end{tabular}

Source: Personal Calculation.

Table 6. Means and distribution of variables.

\begin{tabular}{cccc}
\hline Variables & Moyenne & Skewness & Kurtosis \\
\hline Trust & 4.6 & -.525 & -.560 \\
The communication & 4.7 & -.430 & -.220 \\
The commitment & 4.9 & -.523 & -.623 \\
Satisfaction & 4.6 & -.513 & -.340 \\
Loyalty & 4,9 & -.690 & -.460 \\
\hline
\end{tabular}

Source: Personal Calculation.

Table 7. The impact of trust on loyalty.

\begin{tabular}{ccccc} 
Hypothesis & B & R2 & F0 & $P$ \\
\hline $\begin{array}{c}\text { H1: The more confident consumers feel, } \\
\text { the more loyal they are to the bank }\end{array}$ & .720 & .480 & 119.60 & .000 \\
\hline
\end{tabular}

Source: Personal Calculation.

The trust a customer places in their bank refers to certain credibility, guarantee, or reliability. This credibility can be measured by the bank's ability to execute transactions on time, maintain and stabilize prices (Elissar et al., 2011).

Table 8 presents the results obtained from the assumptions concerning the impact of the commitment on the different dimensions of loyalty. 
Table 8 shows that the model relating engagement to loyalty is significant, with $p(\mathrm{FO})=.000$.

Let us add that their impact is positive since all beta is positive. The model that links commitment to loyalty displays an $\mathrm{R} 2=.622$ so this model is a linear model with good explanatory power.

The regression analyses carried out in this study show that the commitment variable has a significant and positive impact on the loyalty of banking customers in Tunisia.

This is consistent with Eugene's (1998) finding that this type of engagement has the greatest impact on the long-term performance of a relationship and the greatest impact on customer retention.

The result obtained from the assumption on the impact of the communication on the overall measured loyal (Table 9).

Table 9 shows that the model relating communication to loyalty is significant, with a $p(\mathrm{~F} 0)=.000$.

Also, the impact of communication on loyalty is positive since the beta equals .749. Moreover, the model displays $\mathrm{R} 2=.590$. It links communication to loyalty and is a linear model with good explanatory power.

This result implies that banks that are successful in communicating transparent, consistent, and accurate information that can meet customers' expectations are becoming more and more loyal to them. According to the communication is defined as formal sharing and Informal, reliable, and periodic information between partners (Anderson, 1998). If reliable information is not exchanged, problems of understanding and coordination may arise. On the other hand, the more informed the parties are, and regularly, the more confident they will feel (Anderson \& Weitz, 1989).

Table 10 presents the results obtained from the assumption on the impact of satisfaction measured in an overall way on loyalty.

Table 10 shows that the model relating satisfaction and loyalty is significant, with a $p(\mathrm{~F} 0)=.000$. Let us add that the impact of satisfaction on loyalty is positive since beta $=.790>0$. Besides, this model has a good explanatory power since it displays an $\mathrm{R} 2=.773$.

The various regression analyses carried out in this study have also shown that the satisfaction dimension has a significant and positive impact on the loyalty of bank customers. This means that a satisfied customer is more likely to be a loyal customer. This result is consistent with that of (Meyssonnier \& Zakaroui, 2016) defining a satisfied customer as a customer who is likely to intensify their relationship with the company by purchasing several products from it.

To increase customer satisfaction would be to adequately respond to their claims. Indeed, the complaint processing process involves exchanges between the dissatisfied customer and the service provider involved. These exchanges may lead to clearing mechanisms that may meet the expectations of the client (Bhandari et al., 2007). 
Multiple regression was recommended to compare the collective impact of all independent variables on the dependent "loyalty" variable.

The stepwise method was used to limit the multicollinearity between variables (Dhakal, 2018). This method makes it possible to verify the effect of each of the independent variables on the dependent variable via the standardized regression coefficients (the larger this coefficient, the larger the variable in the model) (Table 11).

Table 11 shows that following the Stepwise method, the multiple regression between the dependent variable and our independent variables makes it possible to determine two components that influence the loyalty variable the most. The relationships are positive. And the model has a very good explanatory power since it displays an $\mathrm{R} 2=.750$.

This same table also shows that the communication, satisfaction, and engagement factor, with a standardized beta coefficient of .780 is the one that most affects loyalty.

Table 8. Impact of commitment on loyalty.

\begin{tabular}{ccccc}
\hline Hypothesis & B & R2 & F0 & $P$ \\
$\begin{array}{l}\text { H2: The more bank customers are engaged, the more } \\
\text { loyal they are to the bank }\end{array}$ & .692 & .622 & 168.87 & .000
\end{tabular}

Source: Personal Calculation.

Table 9. The impact of the communication on the overall measured fidelity.

\begin{tabular}{ccccc}
\hline Hypothesis & B & R2 & F0 & $P$ \\
$\begin{array}{l}\text { H3: The more satisfied customers are, the more loyal } \\
\text { they are to the bank }\end{array}$ & .749 & .590 & 158.70 & .000 \\
\hline
\end{tabular}

Source: Personal Calculation.

Table 10. The impact of satisfaction on loyalty.

\begin{tabular}{ccccc}
\hline Hypothesis & B & R2 & F0 & $P$ \\
\hline $\begin{array}{c}\text { H4: Quality communication should increase bank } \\
\text { customer loyalty for the bank }\end{array}$ & .790 & .773 & 180.52 & .000 \\
\hline
\end{tabular}

Source: Personal Calculation.

Table 11. Multiple regression result.

\begin{tabular}{ccccc}
\hline Dependent variable & Independent variable & $\mathrm{R} 2$ & $P$ \\
\hline Loyalty & $\begin{array}{r}\text { The Satisfaction, } \\
\text { the communication and commitment }\end{array}$ & The trust & \\
B & .780 & .230 & .750 & .000 \\
F & 8.898 & 3.553 & \\
\hline
\end{tabular}

Source: Personal Calculation. 


\section{Conclusion}

The starting point is therefore the customer. But the customer is not alone! There are other elements that may interfere with the creation of a product service offering, such as a new law that prohibited the use of raw material in the production cycle. And, there is an association that defends the interests of their members: Others, on the contrary, will be new opportunities that the best will seize.

In Tunisia, and despite the growing interest in studying the relationship approach, no research has yet linked this notion to the banking industry. Thus, the main objective of this work is to verify the impact of the relationship approach, through four dimensions (trust, commitment, satisfaction, and communication) on the loyalty of banking customers in Tunisia.

Moreover, the hypotheses of our study have been validated, demonstrating the impact of each of the relational variables analyzed on loyalty. We first made simple regressions to test the effect of each independent variable on loyalty. Then we performed a multiple regression to determine the most influential variables of our model.

The analysis of the results of the various simple regressions confirmed the existence of a significant relationship between trust, commitment, satisfaction, and communication on the one hand and the loyalty of banking customers in Tunisia on the other hand. Concerning multiple regression analyses, the results showed that the "communication, satisfaction and engagement" factor is the one that has the most important effect on loyalty. Following the results, several recommendations and managerial implications are presented. We hope these results will help bank managers in Tunisia reap the benefits of relationship marketing within organizations.

\section{Theoretical Implications}

This study aimed to explore the main antecedents of customer loyalty and the relationship between customer loyalty and communication, satisfaction, commitment and trust in the banking context. The results reveal a strong association between the variables. This discovering shows the relevance of customer commitment in generating customer loyalty, contributing support to recent expanding interest in the literature on this association (Kumar et al., 2013; Thakur, 2016; Kosiba et al., 2018; Moliner et al., 2013; Parihar et al., 2019).

\section{Managerial Implications}

The study took a pioneering step in establishing the relation between customer loyalty and the component of relations approach in the bank context: loyalty generated by returning customers, and to the positive manners of these customers concerning specific corporations and their associated products or services.

\section{Article Limitations}

However, by analyzing our results, this variable was found to be correlated with 
the same factor. Not being able to study the effect of our independent variables on each of these dimensions has reduced the scope of this study.

\section{Future Avenues of Research}

To remedy our first limitation, future research should consider small and medium-sized banks in several regions in Tunisia. These elements would increase the response rate, give a more representative view of the Tunisian financial market and its population, which was not the objective of this research.

\section{Conflicts of Interest}

The author declares no conflicts of interest regarding the publication of this paper.

\section{References}

Alrubaiee, L., \& Al-Nazer, N. (2010). Investigate the Impact of relationship Marketing Orientation on Customer Loyalty: The Customer's Perspective. International Journal of Marketing Studies, II, 155-174. https://doi.org/10.5539/ijms.v2n1p155

Anderson, E. (1998). Customer Satisfaction and Word of Mouth. Journal of Service Research, 1, 5-17. https://doi.org/10.1177/109467059800100102

Anderson, E., \& Weitz, B. (1989). Determinants of Continuity in Conventional Industrial Channel Dyads. Marketing Science, 8, 310-323. https://doi.org/10.1287/mksc.8.4.310

Azzouzi, M., \& Naoui, F. (2020). Impact de la qualité d'accueil sur la fidélité des clients: Cas de la Banque Populaire. International Journal of Management Sciences, 3.

Benamour, Y., \& Prim, L. (2000). Orientation relationnelle versus transactionnelle du client: Développement d'une échelle dans le secteur bancaire français une étude exploratoire. Cahier de recherche, No. 279, 1-22.

Bergeron, J., Ricard, L., \& Perrien, J. (2003). Les déterminants de la fidélité des clients commerciaux dans l'industrie bancaire canadienne. La Revue Canadienne des Sciences Administratives, 20, 107-120. https://doi.org/10.1111/j.1936-4490.2003.tb00697.x

Bhandari, M. S., Tsarenko, Y., \& Polonsk, M. J. (2007). A Proposed Multi-Dimensional Approach to Evaluating Service Recovery. Journal of Services Marketing, 21, 174-185. https://doi.org/10.1108/08876040710746534

Boyer, A., \& Nefzi, A. (2008). La relation entre la perception de la qualité et la fidélité: Une application aux sites web commerciaux. La Revue des Sciences de Gestion: Direction et Gestion, 43, 37. https://doi.org/10.3917/rsg.234.0037

Bruhn, M. (2000). Information-Based Analysis of Service Quality Gaps: Managing Service Quality by Internal Marketing. Journal of Professional Services Marketing, 21, 105-124. https://doi.org/10.1300/J090v21n02 08

Dhakal, C. (2018). Interpreting the Basic Outputs (SPSS) of Multiple Linear Regression. International Journal of Science and Research (IJSR), 8, 1448-1452.

Elissar, T., Tatiana, Z., \& Soumaya, B. D. (2021). A Framework of Blockchain Technology Adoption: An Investigation of Challenges and Expected Value. Information and Management, 58, Article ID: 103444.

Evrard, Y., Pras, B., \& Roux, E. (1993). Market-Ėtudes et recherches en marketing. Paris: Nathen Éditions. 
Fasnacht, D. (2018). Preparing for the New Reality. In Open Innovation Ecosystems. Management for Professionals (pp. 1-23). Cham: Springer. https://doi.org/10.1007/978-3-319-76394-1

Fawcett, J. et al. (1992). The Relationship of Theory and Research (2nd ed.). Philadelphia, PA: F.A. Davis Company.

Hrishikesh, K., Pramod, P., \& Radhika, M. (2019). Multi-Agent System for Customer Behavior Tracking Using Shoppers' Path or Traversal. 2019 IEEE International Conference on Electrical, Computer and Communication Technologies (ICECCT), Coimbatore, 20-22 February 2019.

Intissar, A., Yousra, H., \& Nadia, T. (2020). Role of Online Collaborative Redistribution Platforms. Journal of Retailing and Consumer Services, 52, Article ID: 101885. https://doi.org/10.1016/j.jretconser.2019.101885

Karim, R. A., \& Habiba, W. (2020). How CRM Components Impact Customer Loyalty: A Case from Bangladesh Banking Industry. Journal of Management Info, 7, 43-61. https://doi.org/10.31580/jmi.v7i2.1165

Keaveney, S. M. (1995). Customer Switching Behavior in Service Industries: An Exploratory Study. Journal of Marketing, 59, 71-82. https://doi.org/10.1177/002224299505900206

Kosiba, J. P. B., Boateng, H., OkoeAmartey, A. F., Boakye, R. O., \& Hinson, R. (2018). Examining Customer Engagement and Brand Loyalty in Retail Banking: The Trustworthiness Influence. International Journal of Retail and Distribution Management, 46, 764-779. https://doi.org/10.1108/IJRDM-08-2017-0163

Kumar, V., Pozza, I. D., \& Ganesh, J. (2013). Revisiting the Satisfaction-Loyalty Relationship: Empirical Generalizations and Directions for Future Research. Journal of Retailing, 89, 246-262. https://doi.org/10.1016/j.jretai.2013.02.001

Melewar, T. C., Foroudi, P., Gupta, S., Kitchen, P. J., \& Foroudi, M. M. (2017). Integrating Identity, Strategy and Communications for Trust, Loyalty and Commitment. $\mathrm{Eu}-$ ropean Journal of Marketing, 51, 572-604. https://doi.org/10.1108/EJM-08-2015-0616

Meyssonnier, F., \& Zakar, M. (2016). Satisfaction du client et efficience du personnel en contact dans la relation de service. Recherche en Science de Gestion, 112, 59-76. https://doi.org/10.3917/resg.112.0059

Moital, M. (2007). An Evaluation of the Factors Influencing the Adoption of E-Commerce in the Purchasing of Leisure Travel by the Residents of Cascais, Portugal. Bournemouth University.

https://eprints.bournemouth.ac.uk/12239/1/Luis Miguel Moital Rodriques.pdf.

Moliner, C., Gracia, E., Lorente, L., \& Martínez-Tur, V. (2013). Structure and Validation of a Contextual Quality of Life Scale for People with Intellectual Disabilities in Social Services: An Organization Oriented Measure from an External Perspective. Perspectivas Em Gestão \& Conhecimento, 3, 80-94.

Morgan, R. M., \& Hunt, S. D. (1994). The Commitment-Trust Theory of Relationship Marketing. Journal of Marketing, 58, 20-38. https://doi.org/10.1177/002224299405800302

Moulins, J.-L., \& Roux, E. (2008). Un modèle tridimensionnel des relations à la marque: de l'image de marque à la fidélité et aux communications de bouche-à-oreille. Proceedings of the 7th International Marketing Trends, Venise, 17-19 January 2008.

Ndubisi, N. O. (2006). Effect of Gender on Customer Loyalty: A Relationship Marketing Approach. Marketing Intelligence \& Planning, 24, 48-61. https://doi.org/10.1108/02634500610641552 
O’Brien, L., \& Jones, C. (1995). Do Rewards Create Loyalty? Harvard Business Review, 73, 75-82.

Paille, P., \& Mucchielli, A. (2003). L'analyse qualitative en sciences humaines et sociale. Paris: Armand Colin (U).

Palmatier, R., \& Steinhoff, L. (2019). Relationship Marketing Strategies. In Relationship Marketing in the Digital Age (pp. 144-180). London: Routledge. https://doi.org/10.4324/9781315143583-5

Parihar, P., Dawra, J., \& Sahay, V. (2019). The Role of Customer Engagement in the Involvement-Loyalty Link. Marketing Intelligence and Planning, 37, 66-79.

https://doi.org/10.1108/MIP-11-2017-0318

Park, S., \& Kim, Y. (2000). Conceptualizing the Attitudinal Loyalty Construct in Recreational Sport Contexts. Journal of Sport Management, 14, 197-207. https://doi.org/10.1123/jsm.14.3.197

Reichheld, F. F., \& Schefter, P. (2000). E-Loyalty: Your Secret Weapon on the Web. Harvard Business Review, 78, 105-113.

Reichheld, F. F., \& Teal, T. (1996). The Loyalty Effect the Hidden Force behind Growth, Profits, and Lasting Value. Boston, MA: Harvard Business School Press.

Rouissi, C., \& Frioui, M. (2014). The Impact of Inflation after the Revolution in Tunisia. Procedia Social and Behavioural Sciences, 109, 246-249.

Stafford, J., \& Bodson, P. (2006). L'analyse multivariée avec SPSS. Quebec City: Presse de l'Université du Québec. https://doi.org/10.2307/j.ctv5j017v

Thakur, R. (2016). The Responsibility to Protect at 15. International Affairs, 92, 415-434. https://doi.org/10.1111/1468-2346.12557

Theron, E., \& Terblanche, N. S. (2010). Dimensions of Relationship Marketing in Business-to-Business Financial Services. International Journal of Market Research, 52, 373-392. https://doi.org/10.2501/S1470785310201326

UNSPECIFIED (1983). Bulletin of the European Communities, No. 3-1983. [EU Commission-Working Document]

Yvonne, P. S., \& Jackman, S. (2002). Customer Profitability Analysis: Frustration Leads to Evolution. New Zealand Journal of Applied Business Research, 1, 125-135. 